Ks. Leszek MISIARCZYK*

\title{
CZY EWAGRIUSZ Z PONTU ZOSTAŁ RZECZYWIŚCIE POTĘPIONY?
}

1. Wstęp. Nie ulega wątpliwości, że w XX w. jesteśmy świadkami wielkiego rozwoju badań nad pismami Ewagriusza z Pontu i jego nauczaniem. Spośród wielu wydarzeń, cztery, jak się wydaje, odegrały kluczową rolę i wprowadzily te badania na nowe tory. Pierwsze to krytyczne wydanie w języku greckim przez państwo Claire i Antoine Guillaumont i Paul'a Gehin'a w słynnej serii Sources Chretiénnes traktatów Mnicha z Pontu, takich jak Practicus ${ }^{1}$, Gnosticus $^{2}$ i De malignis cogitationibus ${ }^{3}$, a także Scholia in Proverbia ${ }^{4}$ i Scholia in Ecclesiasten ${ }^{5}$. Inne pozostają nadal dostępne dla badaczy tylko w wersji Jacques'a P. Migne'a, która jak wiemy, pozostawia wiele do życzenia. Drugie, to nieznana w przeszłości duża liczba odkrytych dzieł Mnicha z Pontu lub ich fragmentów w thumaczeniach orientalnych, na język syryjski i armeński. O wiele wcześniej niż edycja tekstów Ewagriusza w języku greckim, bo już w 1907 r., Sarghissean, mechitarysta z San Lazaro dei Armeni w Wenecji, opublikował tom jego tekstów w tłumaczeniu armeńskim. Wilhelm Frankenberg wydał już na początku XX w. wersję syryjską niektórych traktatów Ewagriusza, np. Antirrheticus wraz z ich retranslacją na język grecki ${ }^{6}$. Tłumaczenia na język syryjski i armeński okazały się bardzo ważne z dwojakiego powodu: umożliwiały dostęp do tekstów Ewagriusza, które zaginęły po grecku oraz pozwalały zidentyfikować jego teksty zachowane po grecku, ale pod imieniem innych autorów, np. Nila z Ancyry ${ }^{7}$. Po trzecie, Claire i Antoine Guillaumont

* Ks. dr hab. Leszek Misiarczyk, prof. UKSW - profesor nadzwyczajny w Instytucie Nauk Historycznych na Wydziale Nauk Historycznych i Społecznych Uniwersytetu Kard. Stefana Wyszyńskiegow Warszawie; e-mail: 1.misiarczyk@uksw.edu.pl.

${ }^{1}$ Por. Évagre le Pontique, Traité pratique ou le Moine, ed. C. Guillaumont - A. Guillaumont, t. 1-2, SCh 170-171, Paris 1971.

${ }^{2}$ Por. Évagre le Pontique, Le Gnostique ou à celui qui est devenu digne de la science, ed. C. Guillaumont - A. Guillaumont, SCh 356, Paris 1989.

${ }^{3}$ Por. Évagre le Pontique, Sur les pensées, ed. P. Géhin - C. Guillaumont - A. Guillaumont, SCh 438, Paris 1998.

${ }^{4}$ Por. Évagre le Pontique, Scholies aux Proverbes, ed. P. Géhin, SCh 340, Paris 1987.

${ }^{5}$ Por. Évagre le Pontique, Scholies à l'Ecclésiaste, ed. P. Géhin, SCh 397, Paris 1993.

${ }^{6}$ Por. W. Frankenberg, Evagrius Ponticus, Berlin 1912.

${ }^{7}$ Por. bibliografia wydań wszystkich tekstów w językach oryginalnych i w tłumaczeniu na język polski w: L. Nieścior, Bibliografia, w: Ewagriusz z Pontu. Pisma ascetyczne, t. 1, ŹM 18, 
odkryli, oprócz znanej dotychczas, drugą wersję syryjską Kephalaia Gnostica, wskazując, że to właśnie ona jest autentyczna ${ }^{8}$. Kilka lat później A. Guillaumont opublikował dwie wersje syryjskie Kephalaia gnostica w tomie Patrologia Orientalis pt. Les six Centuries des „Kephalaia gnostica” d'Évagre le Pontique. Édition critique de la version syriaque commune et édition d'une nouvelle version syriaque intégrale avec une double traduction française, jedną znaną dotychczas jako wersja wspólna (S 1) i druga, niedawno odkryta, którą określił mianem integralnej (S 2) ${ }^{9}$. Gdy okazało się, że wersja syryjska S 2 traktatu zawiera elementy orygenizmu, który został potępiony w 553 r., Guillaumont doszedł do wniosku, że to właśnie ta wersja jest wersją integralna, a S 1, określona mianem wersji wspólnej, została oczyszczona z błędów orygenizmu. Po czwarte wreszcie, w 1962 r. ukazała się monografia A. Guillaumonta w której uznaje on Ewagriusza za postać centralną dla orygenizmu ${ }^{10}$, a za nim powtarza to Francois Refoulé ${ }^{11}$ i inni. I tak oto Ewagriusz, po potępieniu orygenizmu na II soborze w Konstantynopolu w 553 r., a także przywołaniu imiennym na Soborze Konstantynopolitańskim III w 680-681 r. i Nicejskim II w 787 r., przez całe stulecia był postrzegany jako jeden z głównych przedstawicieli orygenizmu. Opinia ta, oparta wcześniej tylko na orzeczeniach soborowych, w XX w. została dodatkowo wzmocniona argumentami naukowymi wybitnego badacza pism Ewagriusza A. Guillaumonta.

\section{Czy Mnich z Pontu rzeczywiście był centralną postacią orygenizmu?} Autorytet naukowy Guillaumonta na całe lata zaważył na opinii o Mnichu z Pontu jako słusznie potępionym przedstawicielu orygenizmu i takie poglądy były powtarzane bezkrytycznie przez następne pokolenia badaczy. Nawet jeśli niektórzy dziwili się temu, że Ewagriusz - wytrawny mistrz życia duchowego - padł sam ofiarą błędu, to jednak brak znajomości języka syryjskiego nie pozwalał na dyskusję z argumentami Guillaumonta. Punktem zwrotnym

Kraków - Tyniec 1998, 47-73; L. Misiarczyk, Osiem logismoi w pismach Ewagriusza z Pontu, Kraków - Tyniec 2007, 387-390.

${ }^{8}$ Por. A. Guillaumont - C. Guillaumont, Le texte veritable des „Gnostica” d'Évagre le Pontique, RHR 142 (1952) 156-205.

${ }^{9}$ Zachowane fragmenty greckie opublikował J. Muyldermans, Evagriana. Extrait de la revue „Muséon”, vol. 42, augmenté de nouveaux fragments grecs inédits, Paris 1931, 52-59; tenże, À travers la tradition manuscrite d'Évagre le Pontique. Essai sur le manuscrits grecs conservés à la Bibliotheque Nationale de Paris, Louvain 1932, 73. 74. 85. 89. 93; a także I. Hausherr, Nouveaux fragments grecs d'Évagre le Pontique, OCP 5 (1939) 229-233; P. Géhin, Evagriana d'un manuscrit basilien, „Muséon” 109 (1966) 59-85, spec. s. 64-66, a wersje syryjskie S 1 i S 2 właśnie A. Guillaumont, Les six Centuries des „Kephalaia gnostica” d'Évagre le Pontique. Édition critique de la version syriaque commune et édition d'une nouvelle version syriaque intégrale avec une double traduction française, Patrologia Orientalis 28/1, Paris 1958.

${ }_{10}$ Por. A. Guillaumont, Les Kephalaia Gnostica d'Evagre le Pontique et l'histoire de l'origenisme chez les Grecs at chez les Syriens, Paris 1962.

${ }^{11}$ Por. F. Refoulé, Évagre fut-il Origéniste, RSPT 47 (1963) 398-402. 
w badaniach nad pismami Ewagriusza okazało się studium Gabriela Bunge na temat relacji pomiędzy gnostycyzmem i orygenizmem ${ }^{12}$. Wykazał on bowiem, że żadne ze znanych i zachowanych do naszych czasów pierwszorzędnych źródeł nie wspomina w ogóle Ewagriusza w okresie tzw. pierwszego sporu orygenistycznego. Co prawda, Elisabeth Clark w swoim studium z 1992 r. powtórzyła jeszcze stare tezy Guillaumonta i Refoulé, że Ewagriusz jest postacią centralną dla orygenizmu, zarzucając Bunge, iż traktuje brak wzmianki o Ewagriuszu w źródłach z V w. i nawet na II Soborze Konstantynopolitańskim (553) jako dowód jego ortodoksyjności, a nie jako bodziec do dalszych poszukiwań innego możliwego wyjaśnienia tego milczenia, ale nie przedstawiła przekonujących argumentów przeciwko jego tezie ${ }^{13}$. Nikt również później w przekonujący sposób nie podważył głównej tezy Bunge, że żadne ze znanych nam pierwszorzędnych źródeł nie wspomina w ogóle Ewagriusza w okresie tzw. pierwszego sporu orygenistycznego. Clark wyraźnie rozwija i radykalizuje myśl A. Guillaumonta na temat wersji S 2 Kephalaia Gnostica jako wiarygodnego źródła orygenizmu Ewagriusza, choć sam Guillaumont był zdecydowanie bardziej ostrożny pisząc: „Pisma Ewagriusza są świadectwem i w pewnym sensie prawdopodobnie produktem orygenizmu, który został potępiony w 400 r.; ale nie jesteśmy w stanie ocenić czy rzeczywiście odegrał on ważną rolę w formowaniu się tego orygenizmu, który został potępiony"14. Bunge uświadomił wszystkim badaczom pism Ewagriusza bardzo ważną rzecz, mianowicie że przyjęcie w punkcie wyjścia złożenia, iż Mnich z Pontu jest heretykiem-orygenistą i interpretowanie $\mathrm{z}$ tej perspektywy jego tekstów jest metodologicznie błędne. Powróciło więc zasadnicze pytanie: jaka była rzeczywista rola Ewagriusza w propagowaniu idei orygenistycznych? Czy taka, jak mu się to od lat przypisuje czy może inna? A może potępienie Ewagriusza jest efektem sfałszowania jego pism w VI wieku? Nie ulega wątpliwości, że Mnich z Pontu nie był postacią centralną podczas tzw. pierwszego sporu orygenistycznego, natomiast $\mathrm{w}$ czasie tzw. drugiego sporu był on postrzegany jako jedna $\mathrm{z}$ postaci centralnych razem z Orygenesem i Dydymem. Jeśli rzeczywiście Bunge ma rację, a wydaje się, że tak, to co się stało, że choć przez cały V w. imię Ewagriusza nie pojawiało się zupełnie w tzw. pierwszym sporze, to w tekstach od połowy VI w. było systematycznie wyklinane w orzeczeniach soborów i tekstach autorów chrześcijańskich właśnie razem z Orygenesem i Dydymem?

\footnotetext{
${ }^{12}$ Por. G. Bunge, Origenismus - Gnosticismus. Zum geistgeschichtlichen Standort des Evagrios Pontikos, VigChr 40 (1986) 24-45.

${ }^{13}$ Por. E. Clark, The Origenist Controversy: The Cultural Construcation of an Early Christian Debate, Princeton 1992, 44: „Bunge uses the absence of explicit mention as a support for Evagrius's basic orthodoxy, rather than as a stimulus for inquiry about other possible interpretation of this silence".

${ }^{14}$ Guillaumont, Les „Kephalaia gnostica” d'Evagre le Pontique et l'histoire de l'Origenisme chez les Grecs et chez les Syriens, s. 123: „L'oeuvre d'Évagre est donc in témoin et dans une certain mesure sans doute un produit de l'origénisme qui fuit condamné en 400; mais elle est venue trop tard pour qu'on puisse estimer qu'elle ait joué un rôle importante dans la formation de cet origénisme tel qu'il fut condamné", thum. własne.
} 
Bunge przełamał w ten sposób monopol Guillaumonta na interpretację pism Ewagriusza z perspektywy orygenizmu szóstowiecznego i późniejszych potępień. Zaczęto podkreślać konieczność całkowitego odwrócenia perspektywy badawczej: najpierw należy zrekonstruować kontekst historyczny życia i dzieł Ewagriusza, a potem w tym kontekście osadzić jego pisma, aby je właściwie rozumieć i interpretować. Poza kontekstem monastycznym niektóre fragmenty jego pism lub całe dzieła mogły rzeczywiście brzmieć heretycko. Taką metodologię - najpierw rekonstrukcja kontekstu historycznego życia i pism Ewagriusza, potem rekonstrukcja jego teologii - przyjęła w swoim studium Julia Konstantinovsky ${ }^{15}$, a jej śladami poszedł Augustine Casiday rozpoczynając od rekonstrukcji Sitz im Leben życia i twórczości literackiej Ewagriusza, by potem $\mathrm{z}$ tej perspektywy analizować sporne elementy jego teologii ${ }^{16}$. W ten sposób uczyniono pierwszy, bardzo poważny i przekonujący krok w kierunku rehabilitacji Ewagriusza i wypada mieć nadzieje, że kolejne opracowania potwierdzą te wstępne wnioski.

Analizując pisma Ewagriusza musimy ciągle pamiętać, że mamy do czynienia $\mathrm{z}$ autorem zajmującym się tematami bliskimi mnichom i życiu ascetycznemu, czego zdawali się nie dostrzegać niektórzy badacze, ekstrapolując fragmenty jego dzieł albo interpretując je tak, jakby były traktatami na temat kosmologii, antropologii, chrystologii czy eschatologii. Widać to doskonale na przykładzie Kephalaia Gnostica, które dla Ewagriusza są tak naprawdę sentencjami dotyczącymi życia monastycznego popularnymi później w Bizancjum i upowszechnionymi zwłaszcza przez Maksyma Wyznawcę czy Szymona Teologa. Stąd też często w dotychczasowych badaniach nad pismami Ewagriusza popełniano błąd, oddzielając Kephalaia czy Epistula ad Melaniam od reszty jego dzieł zachowanych w języku greckim i traktowano je jako najbardziej wiarygodne źródło jego teologii. Dzieła te są ściśle związane z życiem monastycznym, a nie z ezoteryczną teologią czy teoretycznymi dywagacjami o charakterze kosmologicznym i eschatologicznym. Wyrwane zaś z monastycznego kontekstu życia i działalności pisarskiej Mnicha z Pontu nie mogą stanowić wiarygodnego źródła do rekonstrukcji jego teologii. Tym bardziej wersja S 2 Kephalaia, która jak zobaczymy, została najprawdopodobniej sfałszowana przez orygenistów. Podobnie należy interpretować Practicus i Gnosticus, które są również tekstami spisanymi w formie rozdziałów. Tak więc to monastyczny kontekst historyczny czasu i miejsca życia Ewagriusza jest kluczem do interpretacji teologicznej jego tekstów, a nie przyjęcie późniejszych potępień jako założeń wstępnych i projektowanie ich potem na jego życie i teksty ${ }^{17}$.

${ }^{15}$ Por. J. Konstantinovsky, Evagrius Ponticus. The Making of a Gnostic, Farnham 2009.

${ }^{16}$ Taką metodę odczytania na nowo Ewagriusza zaproponował A. Casiday, Reconstructing the Theology of Evagrius Ponticus. Beyond Heresy, Cambridge 2013.

${ }^{17}$ Por. Casiday, Reconstructing the Theology of Evagrius Ponticus, s. 41-42. 
W każdym razie wstępne wnioski, do jakich prowadzą najnowsze badania Casiday'ego w tym obszarze, są następujące ${ }^{18}$ :

a) W żadnym $\mathrm{z}$ tekstów źródłowych $\mathrm{z}$ końca IV i początku $\mathrm{V}$ w. dotyczących pierwszego sporu orygenistycznego nie pojawia się w ogóle imię Ewagriusza. Można oczywiście argumentować, że jego pisma w sposób milczący sprowokowały ten pierwszy spór, ale trudno będzie to wykazać, gdyż argument z milczenia sam z siebie nie wystarczy do uzasadnienia jakiejkolwiek hipotezy. Tym bardziej, że wzmiankowani są Orygenes, a także Ammonios, Dioskur, Euzebiusz, Eutymiusz i Wielcy Bracia. Gdyby więc były jakiekolwiek podejrzenia wobec Ewagriusza, z pewnością zostałyby zachowane do naszych czasów, a nie widać powodów dlaczego miałby on zostać oszczędzony od potępienia. Ewagriusz oczywiście był jednym z monastycznych spadkobierców Orygenesa, ale brakuje dowodów na to, by określić go jako intelektualnego twórcę, którego dzieła zostałyby zaatakowane w 400 r. z powodu orygenizmu. Wszelkie próby uczynienia $\mathrm{z}$ Ewagriusza centralnej postaci pierwszego sporu orygenistycznego nie są oparte na bezpośrednich dowodach źródłowych. Widzimy wyraźnie kontrast z drugim sporem orygenistycznym, podczas którego Mnich z Pontu był wzmiankowany imiennie przez liczne źródła, a kilka z nich wprost odnosi się do Kephalaia Gnostica jako najbardziej problematycznego dzieła. W połowie więc VI w. Ewagriusz i jego Kephalaia Gnostica są w centrum debat o orygenizmie, natomiast w pierwszym sporze - nie.

b) Jeśli brakuje jakichkolwiek dowodów na to, że Ewagriusz był podejrzewany o orygenizm przed początkiem VI w., to oznacza, że brakuje również dowodów na jakiekolwiek przeszkody w rozpowszechnianiu się jego dzieł w języku greckim i w tłumaczeniu ich na inne języki w latach 400-500. To ma zaś konsekwencje w spojrzeniu na rozpowszechnianie się dwóch wersji syryjskich Kephalaia Gnostica. Ponieważ brakuje przekonujących i solidnych dowodów na to, że dzieła Ewagriusza łączono z pierwszym sporem orygenistycznym, nie ma też powodu, aby zakładać, że w tym okresie ktokolwiek podejmował jakiekolwiek kroki w celu „oczyszczenia” Kephalaia Gnostica z jakichkolwiek błędów doktrynalnych, ponieważ nie budziły one w tym okresie znaczących wątpliwości. W konsekwencji więc nie ma żadnych przekonujących dowodów z IV w. i początku V w. na to, że wersja S 2 Kephalaia Gnostica jest wcześniejsza i zostałaby potem oczyszczona z błędów orygenizmu, jak chciał Guillaumont. Nikt jeszcze nie przedstawił pewnych argumentów za większą spójnością pomiędzy niekwestionowanymi dziełami Ewagriusza w języku greckim i wersją Kephalaia Gnostica S 2 niż wersją S 1. Przyjęto bezkrytycznie założenia Guillaumonta, że pisma Mnicha z Pontu należy interpretować z perspektywy S 2 a nie S 1, ale nikt nie udzielił odpowiedzi na pytanie dlaczego właśnie to założenie jest właściwe. Jak to często bywa w nauce, autorytet Guillaumonta zaważył na tym, że jego założenia przyjęto bezkrytycznie, na wiarę - skoro on tak twierdzi, to znaczy, że rzeczywiście

\footnotetext{
${ }^{18}$ Opieram je na wnioskach Casiday, Reconstructing the Theology of Evagrius Ponticus, s. 64-71.
} 
tak jest. Założenie Guillaumonta mogłoby mieć sens, gdyby udało się ustalić, że związek Ewagriusza z orygenizmem potępionym w 543 i 553 r. istnieje pomimo $\mathrm{S} 2$, ale takiego związku nie ma. W każdym razie nie ma żadnych dowodów źródłowych, które potwierdzałyby konieczność oczyszczenia na przełomie IV i V w. traktatu Ewagriusza Kephalaia Gnostica.

W tym kontekście pojawia się oczywiście pytanie o greckie Vorlage dla Kephalaia Gnostica. Joseph Muyldermans i Irénée Hausherr zidentyfikowali i opublikowali niewielkie fragmenty Kephalaia Gnostica zachowane w j. greckim. A. i C. Guillaumont uznali, że są one podobne do wersji syryjskiej S 2. Pytanie jednak zasadnicze, jakie się jawi, jest następujące: czy te niewielkie fragmenty rzeczywiście dowodzą, że S 2 jest tekstem prawdziwym Kephalaia Gnostica? Porównanie i zbieżność greckich fragmentów z S 2 nic nie wnosi do dyskusji poza tym, że pokazuje, iż S 2 bazowała na jakimś tekście greckim, którego te fragmenty są świadkami. Jedynie czego dowodzą, to tego, że już wersja grecka traktatu była zainfekowana błędami orygenizmu. Najważniejszy jest jednak argument chronologiczny: żaden z zachowanych fragmentów greckich Kephalaia Gnostica nie pochodzi z okresu sprzed drugiego sporu orygenistycznego. Nie wnoszą one więc nic nowego do obecnej dyskusji - teksty z okresu drugiego sporu orygenistycznego wzajemnie się potwierdzają, co jest zrozumiałe, ale to jeszcze niczego nie dowodzi.

c) Ważną rolę w określeniu pierwszeństwa jednej z dwóch wersji syryjskich Kephalaia Gnostica mają thumaczenia antyczne na inne języki. Hieronim w Liście 133. wspomina, że istniało tłumaczenie łacińskie wykonane przez Rufina ${ }^{19}$, a w De viris illustribus potwierdza thumaczenie Genadiusza ${ }^{20}$, ale nie zachowały się one do naszych czasów. Bardzo ciekawe jest natomiast świadectwo tłumaczenia armeńskiego Kephalaia Gnostica, ale jak dotychczas istnieje niestety niewiele studiów na jego temat i pozostaje ono jeszcze do przebadania. Hausherr już w latach $30 \mathrm{XX}$ w. ustalił, że thumaczenie armeńskie zostało dokonane na bazie wersji syryjskiej a nie greckiej, a tłumacz dosyć słabo musiał znać język syryjski²1. W bliższych nam czasach Robin Darling Young analizuje wersje armeńskie tekstów Ewagriusza, ale koncentruje się bardziej na badaniu technik translatorskich ${ }^{22}$. Idąc za mechitarystą Sarkisseanem, który wydał wersję armeńską Kephalaia Gnostica, Hausherr datuje ją na ok. rok 450, ale jego studium powstało przed odkryciem przez Guillaumonta wersji S 2, więc nie zastanawiał się, na której wersji syryjskiej oparte jest tłumaczenie armeńskie, gdyż wtedy była znana tylko jedna. Guillaumont z kolei doszedł do wniosku, że wersja armeńska oparta jest na S 1, czyli tej już

\footnotetext{
${ }^{19}$ Por. Hieronymus, Epistula 133, 3.

${ }^{20}$ Por. tenże, De viris illustribus 11.

${ }^{21}$ Por. I. Hausherr, Les versions syriaque et armenienne d'Evagre le Pontique: leur valeur, leur relation, leur utilization, OCP 22 (1931) 69-118.

${ }^{22}$ Por. R.D. Young, The Armenian adaptation of Evagrius' Kephalaia Gnostica w: Origeniana Quinta, ed. R.J. Daly, Leuven 1992, 535-541.
} 
oczyszczonej przez orygenistów. Hipoteza Guillaumonta budzi poważne zastrzeżenia jeszcze z innego powodu: dlaczego orygeniści mieliby oczyszczać wersję S 1 z rzekomych poglądów Ewagriusza, skoro to oni sami zmienili ją, aby go ukazać właśnie jako zwolennika Orygenesa? Kwestia datacji i pochodzenia wersji armeńskiej jest nadal szeroko dyskutowana, m.in. Guillaumont kwestionuje datację Sarkisseana jako zbyt wczesną. Wypada mieć nadzieję, że prowadzone obecnie w Armenii badania nad wersją armeńską Kephalaia Gnostica doprowadzą do bardziej przełomowych wniosków. W każdym razie, jeśli nawet wersja armeńska jest oparta na $S 1$, to daje nam ona argument chronologiczny za powstaniem S 1 ok. 450 r., czyli 50 lat po śmierci Ewagriusza. Jeśli zaś pamiętamy, że wersja armeńska oparta jest na tłumaczeniu syryjskim, a ta z kolei na tekście greckim, to wersja grecka Kephalaia Gnostica musiała być w obiegu już na początku $\mathrm{V}$ w., a syryjska i armeńska ok. 450 roku.

d) Jak wiemy oskarżenia Ewagriusza o to, że w jego pismach pojawia się heretycki orygenizm intensyfikujący się w 1. poł. VI w., a S 1 zostaje przetłumaczone w połowie V, więc ta wspólna wersja Kephalaia Gnostica była znana już ok. 50 lat po śmierci Mnicha z Pontu i ta wersja S 1 pojawia się w rękopisach syryjskich aż po XI w. Nie mamy natomiast, co jest bardzo ciekawe, żadnych źródeł, który potwierdzałyby, że Kephalaia Gnostica budziły jakieś wątpliwości poza wspomnianymi Listami Barsanufiusza i Jana z Gazy, które zostały napisane ok. 540 r. Odpowiadając na list jakiegoś mnicha, Barsanufiusz i Jan dostarczają nam dowodu, że w tym czasie w Palestynie istniały wątpliwości wobec Kephalaia Gnostica. A jeśli tak, to te listy potwierdzają że połowa VI w. jest właściwszym kontekstem dla S 2, owej rzekomo autentycznej orygenistycznej wersji Kephalaia Gnostica. Pamiętajmy ciągle również o tym, że Guillaumont odkrył wersję S 2 z manuskryptu bardzo późnego, bo z XIV wieku.

Są więc poważne i dosyć mocne argumenty za tym, że S 1 jest wcześniejsza od S 2. Pierwsza byłaby już w obiegu ok. 450 r., natomiast druga lepiej odpowiada kontekstowi historycznemu połowy VI w. i drugiego sporu orygenistycznego. Hieronim w swoim Liście do Ktezyfona krytykuje przekonanie, że chrześcijanin może osiągnąć bezgrzeszność, dyskutując relację pomiędzy

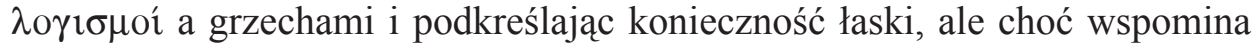
Ewagriusza, to nie postrzega go jako heretyka ${ }^{23}$. Prawdopodobnie pisma Ewagriusza zostały potraktowane bardzo wybiórczo, przepisywano z nich tylko te fragmenty, które były przydatne do formacji monastycznej, tworząc kolekcje lektur dla mnichów, dodawano je lub skracano i wyrywano z pierwotnego kontekstu. Nie wykluczone, że S 2 padła ofiarą owych admiratorów Ewagriusza, jak Stefan bar Sudaili, którzy podpierali się nimi w głoszeniu swoich orygenistycznych poglądów i dlatego został on potępiony. W ten sposób wersja $\mathrm{S} 2$ jest świadkiem wplątania Ewagriusza w drugi spór orygenistyczny, które stało się przyczyną jego potępienia. Potępiono jednak nie Ewagriusza, a raczej

\footnotetext{
${ }^{23}$ Por. Hieronymus, Epistula 133.
} 
„ewagrianizm” VI wieku. Musimy oczywiście pamiętać, że są to pierwsze wstępne wnioski badań z ostatnich lat i duże zasługi położył tutaj A. Casiday. Potrzeba dalszych badań, które miejmy nadzieję będą prowadzone, ale to, co najważniejsze, już się dokonało, czyli próba uwolnienia badań na tekstami Ewagriusza z metodologicznego klinczu interpretowania ich z perspektywy jego późniejszego oskarżenia o orygenizm i potępienia. W takim nowym kontekście, spróbujmy spojrzeć jeszcze raz na potępienia nauki Mnicha z Pontu na soborach kościelnych.

3. Soborowe potępienia Ewagriusza. Kiedy badacze piszą o potępieniu Ewagriusza, zazwyczaj odnoszą się do dokumentów Soboru Konstantynopolitańskiego II (553) ${ }^{24}$. Paradoks polega jednak na tym, że dokładniejsze analiza tekstów zarówno Soboru Konstantynopolitańskiego II, jak też Canones Concilii adversus Origenem, pokazuje, że Mnich z Pontu nie jest w nich w ogóle wzmiankowany imiennie ${ }^{25}$. Kanon 11. Soboru Konstantynopolitańskiego II (553) wspomina Ariusza, Eunomiusza, Macedoniusza, Apolinarego, Nestoriusza, Eutychesa i Orygenesa, ale brakuje jakiejkolwiek wzmianki o Ewagriuszu:

„Kto nie odrzuca Ariusza, Eunomiusza, Macedoniusza, Apolinarego, Nestoriusza, Eutychesa i Orygenesa wraz z ich bezbożnymi pismami i wszystkich innych heretyków, którzy zostali potępieni i odrzuceni przez święty, katolicki i apostolski Kościół i przez cztery wymienione wyżej święte sobory oraz tych, którzy podzielali lub podzielają poglądy podobne do poglądów wspomnianych heretyków i trwają aż do śmierci w swojej bezbożności - niech będzie wyklęty"26.

W kanonie 12. tego samego soboru jest ostrzeżenie dla każdego, kto „broni bezbożnego Teodora z Mopsuestii”, a potem jest on jeszcze wspominany trzy razy: jako „bezbożny Teodor”, drugi raz bez określenia „bezbożny”, a trzeci jako „arcybezbożny Teodor i jego bezbożne pisma"27. W kanonie 13. jest natomiast wzmianka o „bezbożnych pismach Teodoreta”, a w kanonie 14. o Ibasie, który zaprzeczał Bożemu Macierzyństwu Maryi oraz o „bezbożnym Apolinarym"28. Jak widać, imię Ewagriusza zupełnie się tutaj nie pojawia i brak

${ }^{24}$ Por. Concilium Constantinopolitanum II (553), Sententia adversus ,"Tria Capitula” et Anathematismi adversus ,,Tria Capitula”, ŹMT 24 [tekst grecko-polski, opr. A. Baron - H. Pietras, Kraków 2001 = DSP 1], 262-303.

${ }^{25}$ Słusznie piszą o Ewagriuszu i Synodzie Konstantynopolitańskim (543) A. Baron i H. Pietras (DSP 1, 311 nota 11), wyjaśniając: „Ewagriusz z Pontu (345-399), mnich potępiony imiennie przez Justyniana w 553 r. (por. Mansi IX, 396-400 i 403C) za orygenizm oraz przez jeden z synodów w Konstantynopolu".

${ }^{26}$ Concilium Constantinopolitanum II (553), Anathematismi adversus ,, Tria capitula” XI, DSP 1, 294-297.

${ }^{27}$ Por. tamże XII, DSP 1, 297-299.

${ }^{28}$ Por. tamże XIII-XIV, DSP 1, 300-301. 
wzmianki o nim dobrze koresponduje z innymi źródłami z V w. w których, jak wykazał Casiday, nie pojawiają się oskarżenia go o orygenizm.

Pierwszym historycznie dokumentem, w którym Mnich z Pontu pojawia się imiennie jako heretyk, są orzeczenia Synodu Laterańskiego (649). Zwołany przez papieża Marcina I w celu zwalczenia monoteletyzmu w kanonie 18. nakazuje wiernym:

„Jeśli ktoś według wiary świętych Ojców zgodnie z nami i jednakowo nie odrzuci i nie wyklnie duszą i ustami wszystkich [...] - to jest Sabeliusza, Ariusza, Eunomiusza, Macedoniusza, Apolinarego, Polemona, Eutychesa, Dioskura, Tymoteusza Elurusa, Sewera, Teodozjusza, Kollutusa, Temistusza, Pawła z Samosat, Diodora, Teodora, Nestoriusza, Teodulusa z Persji, Orygenesa, Dydyma i Ewagriusza i wszystkich pozostałych heretyków"29.

Synod przytacza te wyklęcia powołując się, co prawda, na wcześniejszą wiarę świętych Ojców, ale, jak widzieliśmy, tylu imion nie ma w orzeczeniach z 553 r. Mamy tam Ariusza, Eunomiusza, Macedoniusza, Apolinarego, Nestoriusza, Eutychesa, Orygenesa, Teodora z Mopsuestii i Ibasa. Zauważmy, że początek listy, z wyjątkiem dodanego Sabeliusza, jest taki sam: Ariusz, Eunomiusz, Macedoniusz, Apolinary, potem dodany jest Polemon, a Nestoriusz przesunięty jest dalej i wraca Eutyches. Dalej, dodani są Dioskur, Elurus, Sewer, Kollutus, Temistusz, Paweł z Samosat, Diodor, Teodor i Nestoriusz, a na końcu,

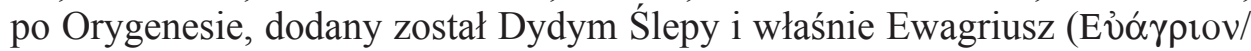
Evagrium). Kanon 18. Synodu Laterańskiego nie precyzuje jednak, jakie wcześniejsze synody lub sobory potępiły wspomnianych wyżej heretyków, ale możemy się domyślać, że chodzi o sobór z 553 r., którego kanony wymieniają kilku z nich imiennie: Ariusza, Eunomiusza, Macedoniusza, Apolinarego, Nestoriusza, Eutychesa, Orygenesa, Teodora z Mopsuestii i Ibasa. W przypadku zarówno Dydyma, jak też Ewagriusza, nie znamy żadnych wcześniejszych orzeczeń soborów, które wymieniałyby ich imiennie jako heretyków. Niektórzy badacze podkreślają, że nie wykluczone jest, iż akta Soboru Konstantynopolitańskiego II (553) nie są kompletne, a w przeszłości mogła istnieć taka ich wersja, w której imię Mnicha z Pontu mogło być zawarte ${ }^{30}$. Takiego zdania był zresztą już wcześniej A. Guillaumont, który opierając się na świadectwie Cyryla ze Scytopolis i Ewagriusza Scholastyka, sądził, że, choć nie byli oni uczestnikami soboru, to jednak mieli dostęp do tej pierwotnej wersji akt

${ }^{29}$ Concilium Lateranense (649) 18, w: Sanctorum Conciliorum Nova et Amplissima Collectio, Mansi X 863: „Si quis sec. s. Patres consonanter nobis pariterque fide non respuit et anathematizat anima et ore omnes [...] - id est, Sabellium, Arium, Eunomium, Macedonium, Apollinarem. Polemonem, Eutychen, Dioscurum, Timotheum Aelurum, Severum, Theodosium, Colluthum, Themistium, Paulum Samosatenum, Diodorum, Theodorum, Nestorium,Theodulum Persam, Origenem, Didymum, Evagrium, et compendiose omnes reliquos haereticos".

${ }^{30}$ Por. L. Dysinger, The Condemnation of Evagrius Reconsidered, Paper read at the Oxford Patristic Conference, August 22, 2003, https://www.academia.edu/10129054/The_Condemnation of_Evagrius_Reconsidered [dostęp: 04.03.2016]. 
soborowych, w których Ewagriusz był wymieniany imiennie ${ }^{31}$. Nic nam jednak nie wiadomo, aby jakaś pierwotna wersja tekstów soborowych zaginęła. Zobaczmy jednak teksty Cyryla i Ewagriusza Scholastyka.

W Żywocie św. Cyriaka Cyryla ze Scytopolis ${ }^{32}$, kiedy mnisi zastanawiaja się czy nauki o preegzystencji i apokatastazie są obojętne i bezpieczne, przytaczając za tym argument z Mowy Grzegorza z Nazjanzu ${ }^{33}$, starzec (Cyriak) odpowiada, że nauki o preegzystencji nie są obojętne, ale szkodliwe i bluźniercze. A mianowicie głoszą oni (orygeniści), że nie ma jednego Chrystusa w Trójcy; ciała po zmartwychwstaniu pójdą na całkowitą zatratę, a ciało Chrystusa jako pierwsze; Trójca Święta nie stworzyła świata; a w czasie apokatastazy wszystkie byty, także demony, będą w stanie tworzyć eony; nasze ciała powstaną eteryczne i sferyczne tak jak ciało Chrystusa, a w czasie apokatastazy będziemy równi Chrystusowi ${ }^{34}$. I w takim kontekście pojawia się interesujący nas fragment:

„Jakie piekło wypluło takie nauki? Nie od Boga nauczyli się tego! Nie od Boga, który mówił przez proroków i apostołów, ale od Pitagorasa i Platona,

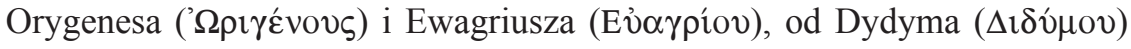
przejęli te ohydne i bezbożne nauki" ${ }^{35}$.

Cyriak wyraźnie więc łączy Orygensa, Ewagriusza i Dydyma z poglądami orygenistów. Z kolei w Żywocie świętego Saby Cyryl wspomina o tym, że gdy Agapetos został nowym przełożonym w Nowej Laurze po Pawle, który uciekł, czterech mnichów przyjętych przez niego wcześniej rozprawiało o Orygenesie. Jednym z nich był niejaki Nonnos, który ,podając się za chrześcijanina i udając bogobojność, wyznawał poglądy bezbożnych pogan, Judejczyków i manichejczyków oraz bajki Orygenesa, Ewagriusza i Dydyma o preegzystencji”36. Cyryl odnosi się także do orzeczeń II Soboru Konstantynopolitańskiego (553):

„Kiedy więc święty i powszechny sobór zebrał się w Konstantynopolu w obecności czterech patriarchów, którzy się na to zgodzili, rzucono wspólną

${ }^{31}$ Por. A. Guillaumont, Évagre et les anathématisme antiorigénistes de 553, StPatr 12 (1961) 219-226; tenże, Les Kephalaia Gnostica d'Evagre le Pontique et l'histoire de l'origenisme chez les Grecs at chez les Syriens, Paris 1962, 136nn.

32 Por. Cyrillus Scytopolitanus, Vita S. Cyriaci 12-13. Zob. R. Kosiński, Wstęp. Cyryl ze Scytopolis i jego dzieła, w: Cyryl ze Scytopolis, Żywoty mnichów palestyńskich, ŹM 60, Kraków Tyniec 2011, 11-92.

${ }^{33}$ Por. Gregorius Nazianzenus, Oratio 27, 10.

${ }^{34}$ Por. Cyrillus Scytopolitanus, Vita S. Cyriaci 12.

${ }^{35}$ Tamże 13, ed. E. Schwartz, Kyrillos von Skythopolis, TU 9/2, Leipzig 1939, 230, thum. E. Dąbrowska: Cyryl ze Scytopolis, Żywot abba Cyriaka za laury Souka, w: Cyryl ze Scytopolis, Żywoty mnichów palestyńskich, ŹM 60, Kraków - Tyniec 2011, 463.

${ }^{36}$ Tenże, Vita S. Sabae 30, ed. E. Schwartz, Kyrillos von Skythopolis, TU 9/2, Leipzig 1939, 89, thum. E. Dąbrowska, Cyryl ze Scytopolis, Żywot świętego ojca naszego Saby, w: Cyryl ze Scytopolis, w: Żywoty mnichów palestyńskich, ŹM 60, 304-305. 
i powszechną anatemę na Orygenesa, Teodora z Mopsuestii oraz nauczanie

Ewagriusza i Dydyma o preegzystencji i apokatastazie" ${ }^{\prime 37}$.

Problem tylko w tym, że tych potępień nie ma w ogóle w aktach II Soboru Konstantynopolitańskiego. Diekamp słusznie od dawna już podkreślał, że potępienie Orygenesa dokonało się na wniosek Justyniana najprawdopodobniej jeszcze przed formalnym otwarciem obrad soboru i dlatego nie znalazło się ono w zbiorze akt, a Cyryl błędnie utożsamił wszystko z soborem ${ }^{38}$. Wiemy, że od połowy IV w. w Konstantynopolu działały tzw. synody endemiczne, czyli spotkania przypadkowo obecnych w mieście biskupów w celu rozstrzygnięcia jakichś kwestii ważnych dla cesarzy i Kościoła, a niecierpiących zwłoki ${ }^{39}$. W przypadku Orygenesa sytuacja jest prostsza, gdyż zachował się do naszych czasów list Justyniana - Epistula ad Synodum de Origene - w którym obwieszcza on ojcom soborowym potępienie Orygenesa. Natomiast w przypadku Ewagriusza takiego listu nie ma. Nie wykluczone więc, że zostałby on potępiony właśnie podczas takiego synodu endemicznego albo podczas jakiegoś spotkania biskupów przybyłych na sobór w 553 r., ale jeszcze przed jego oficjalnym rozpoczęciem. Powstaje jednak zasadnicze pytanie czy potępienie przed oficjalnym rozpoczęciem soboru ma jakąkolwiek wartość, jeśli nie zostało dokonane podczas jednej z oficjalnych sesji soboru. Cyryl wspomina o potępieniu Orygenesa, Teodora, Ewagriusza i Dydyma, ale jak widzieliśmy wcześniej, w aktach soboru jest tylko Orygenes i Teodor, a nie ma Ewagriusza i Dydyma. Badacze pism Cyryla podkreślaja, że ponieważ był on zagorzałym przeciwnikiem orygenizmu, w swoich opisach był też bardzo stronniczy i nie wszystkim jego stwierdzeniom należy dawać wiarę ${ }^{40}$. Ponadto, jego Żywoty powstały w połowie VI w., a więc wtedy, gdy Ewagriusz był już wyraźnie „wplątany” w orygenizm i z tej perspektywy oceniał jego nauczanie. Z kolei Ewagriusz Scholastyk w swojej Historii Kościoła wspomina co prawda o tym, że Rufus, przełożony klasztoru Teodozjusza, i Konon z klasztoru Saby przybyli do Konstantynopola i ,zaczęli poruszać sprawy związane z Orygenesem, a także Ewagriuszem i Dydymem”, ale Teodor, biskup Kapadocji, skierował ich uwagę na osobę Teodora z Mopsuestii, Teodoreta i Ibasa ${ }^{41}$. Dalej, informuje, że opierając się na pismach skierowanych przeciwko naukom Orygenesa

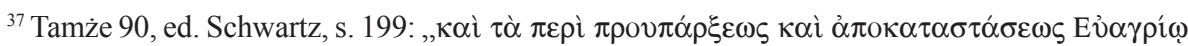

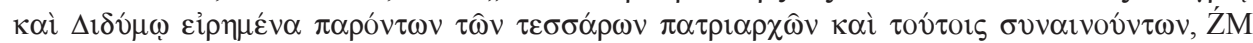
60,414 .

${ }^{38}$ Por. F. Diekamp, Die origenistischen Streitigkeiten im sechsten Jahrhunderte, Münster 1899, $66 n n$.

39 Por. R. Potz, Patriarch und Synode in Konstantinopel, Wien 1971; E. Przekop, Wschodnie patriarchaty starożytne, Warszawa 1984, 94-100; A. Baron, Synody czasów upadku i przemiany Imperium Rzymskiego na Zachodzie, PS 29 (2011) 7.

${ }^{40}$ Por. D. Hombergen, The Second Origenist Controversy. A New Perspective on Cyril of Scythopolis' Monastic Biographies as Historical Sources for Sixth-Century Origenism, Roma 2001.

${ }^{41}$ Evagrius Scholasticus, HE IV 38, PG 86, 2780A, tłum. S. Kazikowski, w: Ewagriusz Scholastyk, Historia Kościoła, Warszawa 1990, 213. 
oraz naśladowcom jego bezbożności i błędu ,Justynian zapytał w tej sprawie zebranych na soborze Ojców, załączając kopię skargi pisemnej, jak również list, który swego czasu nadesłał w tej sprawie Wigiliusz"42. Ewagriusz Scholastyk potwierdza więc, że to Justynian podjął inicjatywę w sprawie Orygenesa i jego uczniów, a Ojców soborowych jedynie zapytał w tej sprawie. Interwencja zaś cesarska została dokonana na wniosek jakiejś skargi pisemnej, choć nie wiemy czyjej, a także listu papieża Wigiliusza. Sobór, według Ewagriusza Scholastyka, wystapił ,przeciw Orygenesowi oraz przeciw tym, którzy pobłądzili tak jak on, przesłał na ręce Justyniana sprawozdanie z obrad"43. Następnie przytacza fragmenty tego sprawozdania, ale imiennie jest w nich wymieniony tylko Orygenes, natomiast po cytatach dodaje:

„Ojcowie soborowi przytoczyli również wiele innych bluźnierczych wypo-

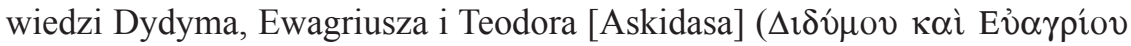

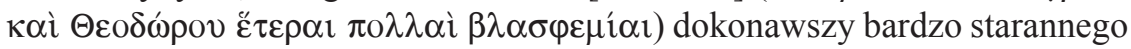
wyboru tekstów o tej właśnie tematyce" ${ }^{44}$.

Nie wspomina więc nic o tym, że zostali oni potępieni przez sobór, ale że to potępienie miało znajdować się w dodatku do reskryptu przygotowanego dla cesarza Justyniana. Ten dokument mógł być podstawą do wydania późniejszych anatematyzmów, w których wspominani są mnisi palestyńscy rozprawiający o Orygenesie, Pitagorasie i Plotynie, ale nie ma w nich Ewagriusza. Wspomniane teksty potwierdzają kontrowersje w środowiskach mnichów palestyńskich, tzw. izochrystów, którzy pewnie powoływali się na Orygenesa, Dydyma i Ewagriusza, ale ich świadectwa na temat soboru z 553 r. są wątpliwe. Widzieliśmy bowiem, że imię Ewagriusza nie pojawia się w ogóle w tekstach Soboru Konstantynopolitańskiego II, ani w kanonach tego soboru przeciw Orygensowi. Guillumont przekonywał, że wyżej wspomniane świadectwa Cyryla i Ewagriusza Scholastyka o potępieniu Mnicha z Pontu w 553 r. potwierdza Synod Laterański (649), ale jak widzieliśmy, ta wzmianka jest bardzo ogólnikowa i nie odwołuje się do konkretnego synodu czy soboru, ani nie mówi za co mieliby oni być potępieni. Nie może więc być traktowana jako dowód, że w 553 r. Ewagriusz Pontyjski rzeczywiście został potępiony. Ewagriusz Scholastyk pisał ogólnie o „bluźnierstwach Dydyma, Ewagriusza i Teodora" nie precyzując, co im zarzucano, natomiast Cyryl raz wspomina o „bajkach Orygenesa, Ewagriusza i Dydyma o preegzystencji”, innym razem podkreśla, że największe dyskusje i wątpliwości budziła nauka orygenistów o preegzystencji i apokatastazie. Wcześniej jednak przytacza poglądy orygenistów: przyjmują jednego Chrystusa w Trójcy; ciała po zmartwychwstaniu pójdą na całkowitą zatratę, a jako pierwsze ciało Chrystusa; Trójca Święta nie stworzyła świata; w czasie apokatastazy wszystkie byty, także demony,

\footnotetext{
${ }^{42}$ Tamże IV 38, PG 86, 2782, tłum. Kazikowski, s. 215.

${ }^{43}$ Tamże, PG 86, 2783, tłum. Kazikowski, s. 216.

${ }^{44}$ Tamże.
} 
będą w stanie tworzyć eony; nasze ciała powstaną eteryczne i sferyczne tak jak ciało Chrystusa, a w czasie apokatastazy wszyscy będziemy równi Chrystusowi. Zachowane do naszych czasów teksty Ewagriusza i badania nad nimi nie potwierdzają, że preegzystencja i apokatastaza były dla niego ważnymi tematami. Oczywiście pojawiają się one w całym systemie Ewagriańskiej kosmologii i eschatologii, ale poza traktatem Kephalaia Gnostica nie stanowią centrum jego nauki koncentrującej się wyraźnie na tematyce ascetycznej, ośmiu namiętnych myślach i duchowej gnozie. Guillaumont, a za nim Refoulé i Grillmeier, słusznie podkreślają, że najbardziej kontrowersyjnym tematem Ewagriusza jest chrystologia, a konkretnie sugerowanie jakoby nie odwieczny Logos stał się człowiekiem, ale preegzystujący vov̂s Chrystusa jako człowieka, co oczywiście podważałoby tajemnicę wcielenia. Temat wymaga głębszego potraktowania przy innej okazji, tutaj wracamy do potępień soborowych. Ponieważ Ewagriusz nie jest potępiony ani przez II Sobór Konstantynopolitański, ani w tzw. 14 anatematyzmach, z których w 11 wyraźnie został potępiony Orygenes, być może rację mają Arkadiusz Baron i Henryk Pietras pisząc, że Ewagriusz został potępiony przez jakiś synod w Konstantynopolu i Justyniana przed samym II Soborem Konstantynopolitańskim.

Od wielu już lat trwa dyskusja wśród badaczy na temat słynnych 15 anatematyzmów przeciw Orygenesowi. Ich tekst został odkryty w XVII w. przez Paula Lambecka, bibliotekarza we Wiedniu, w rękopisie noszącym tytuł $\mathrm{Ka}$ nony 165 Ojców świętego V Synodu w Konstantynopolu. Wielu jednak późniejszych uczonych wyrażało wątpliwości wobec takiej identyfikacji, gdyż nie znano tego typu dokumentu. Ewagriusz Scholastyk wspominał o potępieniu Orygenesa specjalnymi anatemami na II Soborze Konstantynopolitańskim, ale również powątpiewano $\mathrm{w}$ jego świadectwo. $\mathrm{W}$ tej kwestii badacze dzielą się na dwie grupy: jedni uznaja, że te wyklęcia zostały włączone do dokumentów soboru z 553 r., a Orygenes byłby potępiony dwa razy: pierwszy raz sam przed ośmioma sesjami, a drugi raz po nich razem z Dydymem i Ewagriuszem ${ }^{45}$, inni są odmiennego zdania i przypuszczają, że zostały one ogłoszone na lokalnym synodzie w Konstantynopolu w $543 \mathrm{r}^{46}$, jeszcze inni proponują rozwiązanie pośrednie precyzując, iż nawet jeśli owe 15 anatematyzmów zostało ustalone na lokalnym synodzie z 543 r., przed oficjalnymi sesjami Soboru Konstantynopolitańskiego z 553 r., to i tak w 11. kanonie tegoż soboru Orygenes został potępiony, a więc w praktyce sobór z 553 r. ratyfikowałby akta synodu z $543 \mathrm{r}$. i nie ma o co kruszyć zbroi. O ile jednak w przypadku Orygenesa takie rozumowanie może być zaakceptowane, o tyle w przypadku Ewagriusza nie, gdyż jego imię nie pojawia się ani w aktach II Soboru Konstantynopolitańskiego ani w 15 Anatematyzmach przeciw Orygenesowi, ani również w Liście cesarza

${ }^{45}$ Takiego zdania był H. Noris (Dissertatio Historica de Synodo Quinta Oecumenica, Viennae 1703), innego zdania zaś był J. Garnier (De quinta synodo generali, Lutetiae Parisiorum 1684).

${ }^{46}$ Por. Ch.J. Hefele, The History of the Councils of the Church from the original Documents, IV, Edinburgh 1895, 217nn. 
Justyniana o Orygenesie. W tym ostatnim dokumencie w punkcie 10. czytamy, że cesarza wyklina „Orygenesa i każdego, kto naucza i zachowuje podobne doktryny" "77, ale określenie jest ogólnikowe i Ewagriusz nie pojawia się w nim imiennie. Charles-Joseph Héfélé przypuszcza, że akta synodu w Konstantynopolu z 543 r. to po prostu List Justyniana do Menasa, lecz w nich również nie pojawia się imię Ewagriusza. Nawet więc jeśli Mnich z Pontu zostałby potępiony przez Justyniana lub synod lokalny w Konstantynopolu z 543 r., lub jakiś inny synod endemiczny, orzeczenia te nie zostały włączone do oficjalnych akt II Soboru Konstantynopolitańskiego i wydaje się, iż nie mają one mocy prawnej.

Pierwszym tekstem w którym po raz pierwszy imiennie pojawia się Ewagriusz są akta III Soboru Konstantynopolitańskiego z lat 680-681. W wykładzie wiary ojcowie soborowi podkreślają zaraz na początku (pkt. 3), że sobór „idąc niewzruszenie prostą drogą wyznaczoną przez świętych i godnych zaufania Ojców, w duchu pobożności we wszystkim zgodnie rozbrzmiewa wraz z pięcioma świętymi i ekumenicznymi soborami”"48. Dalej mowa jest o poszczególnych soborach zwołanych przeciwko różnym heretykom:

„Dlatego nasz święty i ekumeniczny sobór całkowicie odrzuciwszy zakradający się już od jakiegoś czasu bezbożny błąd idąc niewzruszenie prostą drogą wyznaczoną przez świętych i godnych zaufania Ojców, w duchu pobożności we wszystkim zgodnie rozbrzmiewa wraz z pięcioma świętymi i ekumenicznymi soborami. Mówimy tu o trzystu tych Ojcach zebranych w Nicei przeciwko szaleństwu Ariusza, [...] następnie o soborze w Konstantynopolu [...] przeciwko osobie Macedoniusza pneumatomacha oraz bezbożnego Apolinarego; o pierwszym soborze w Efezie [...] przeciwko Nestoriuszowi; a także o soborze w Chalcedonie i 630 natchnionych Ojcach, którzy odrzucili nienawidzących Boga: Eutychesa i Dioskora; jak również ostatnim z nich, piątym świętym soborze, który zebrał się w Konstantynopolu przeciwko Teodorowi z Mopsuestii, Orygenesowi, Didymowi, Ewagriuszowi, przeciwko pismom Teodoreta wymierzonym w dwanaście artykułów sławnego Cyryla oraz przeciwko listowi, o którym mówi się, że został napisany przez Ibasa do Persa Marina"49.

Dla nas najważniejsza jest $\mathrm{w}$ tym fragmencie informacja o tym, że po Nicei, Konstantynopolu I, Efezie i Chalcedonie wspominane jest potępienie podczas II Soboru Konstantynopolitańskiego Teodora z Mopsuestii, Orygenesa, Dydyma, Ewagriusza i Teodoreta. Jeśli porównamy tę listę z imionami zawartymi w samym soborze z 553 r. - czyli Ariusz, Eunomiusz, Macedoniusz, Apolinary, Nestoriusz, Eutyches i Orygenes, a także Teodor i Teodoret - zauważymy, że w większości imiona powtarzają się z wyjątkiem właśnie Dydyma i Ewagriusza. Ci dwaj ostatni są nieobecni w aktach II Soboru

\footnotetext{
${ }^{47}$ Por. tamże, s. 220.

${ }^{48}$ Concilium Constantinopolitanum III (680-681), Terminus 3, DSP 1, 308-309.

${ }^{49}$ Tamże 3-4, DSP 1, 308-311.
} 
Konstantynopolitańskiego, ale wzmiankuje o nich Cyryl ze Scytopolis, Ewagriusz Scholastyk i Synod Laterański (649). III Sobór Konstantynopolitański powtarzałby więc raczej, wbrew temu, co się twierdzi, opinię o potępieniu Dydyma i Ewagriusza nie za soborem z 553 r., ale za jakimś innym potępieniem. Pytanie zasadnicze, jakie narzuca się w tym momencie, jest następujące: na podstawie jakiego wcześniejszego potępienia III Sobór Konstantynopolitański przypisał potępienie Orygenesa, Dydyma i Ewagriusza dwom wcześniejszym soborom? Na to pytanie jak na razie nie ma odpowiedzi. Dalej, III Sobór Konstantynopolitański tak naprawdę jedynie powtarza wcześniejsze potępienia, a sam niczego w tej materii nie czyni. To samo potępienie powtórzy następny sobór powszechny zwołany do Nicei w $787 \mathrm{r}$.

Sobór Nicejski II praktycznie powtarza listę heretyków z Soboru Konstantynopolitańskiego III. W wyznaniu wiary czytamy:

„Wstrętem przejmuje nas Ariusz, którego wyłączamy ( $\alpha \nu \alpha \theta \varepsilon \mu \alpha \tau i \zeta o \mu \varepsilon v)$ ze wspólnoty Kościoła, a wraz z nim jego zwolenników i współwyznawców jego szalonej i zgubnej doktryny, oraz Mecedoniusza i tych, którzy są przy nim, słusznie nazwanych pneumatomachami [...]. Nasza nauka opiera się na tym, co po raz pierwszy ogłosił jako dogmat sobór w Efezie, który usunął z Kościoła bezbożnego Nestoriusza wraz z jego uczniami, ponieważ wprowadzał dwoistość osób w Chrystusie [...] Uznajemy w Nim doskonałego Boga i doskonałego człowieka, jak to ogłosił sobór w Chalcedonie, wypędzając z Kościoła Eutychesa i Dioskora, którzy bluźnierczo mówili o „bożym zamieszkiwaniu”. Dołączamy do tych heretyków Sewera, Piotra i innych, powiązanych ze sobą łańcuchem najrozmaitszych bluźnierstw. Wraz z nimi potępiamy i odrzucamy błędy Orygenesa i Ewagriusza oraz wymysły Didyma, tak jak uznał to za wła-

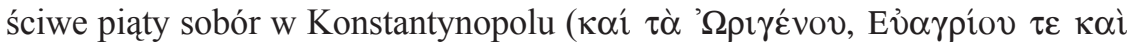

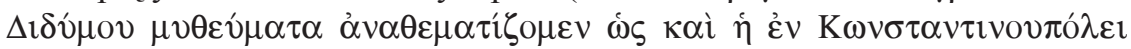

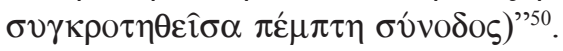

Sobór powtarza wcześniejsze potępienia Ariusza, Macedoniusza, Nestoriusza, Eutychesa, Dioskora, Sewera, Piotra, Orygensa, Ewagriusza i Dydyma. Gdybyśmy chcieli zebrać razem wszystkie potępienia związane z Ewagriuszem, to wyglądałyby one tak:

\begin{tabular}{|c|c|c|c|c|c|c|}
\hline $\begin{array}{c}\text { Sobór } \\
\text { z 553 r. }\end{array}$ & $\begin{array}{c}\text { Żywot } \\
\text { Cyriaka } \\
\mathbf{1 2 - 1 3}\end{array}$ & $\begin{array}{c}\text { Zywot } \\
\text { Saby 30 }\end{array}$ & $\begin{array}{c}\text { Zywot } \\
\text { Saby 90 }\end{array}$ & $\begin{array}{c}\text { Synod laterański } \\
\text { z 649 r. }\end{array}$ & $\begin{array}{c}\text { Sobór } \\
\text { z 680-681 r. }\end{array}$ & $\begin{array}{c}\text { Sobór } \\
\text { z 787 r. }\end{array}$ \\
\hline & & & & Sabeliusz & & \\
\hline Ariusz & & & & Ariusz & Ariusz & Ariusz \\
\hline Eunomiusz & & & & Eunomiusz & & \\
\hline Macedoniusz & & & & Macedoniusz & Macedoniusz & Macedoniusz \\
\hline Apolinary & & & & Apolinary & Apolinary & \\
\hline
\end{tabular}

${ }^{50}$ Concilium Nicaenum II (787), Terminus 8-11, DSP 1, 334-335. 


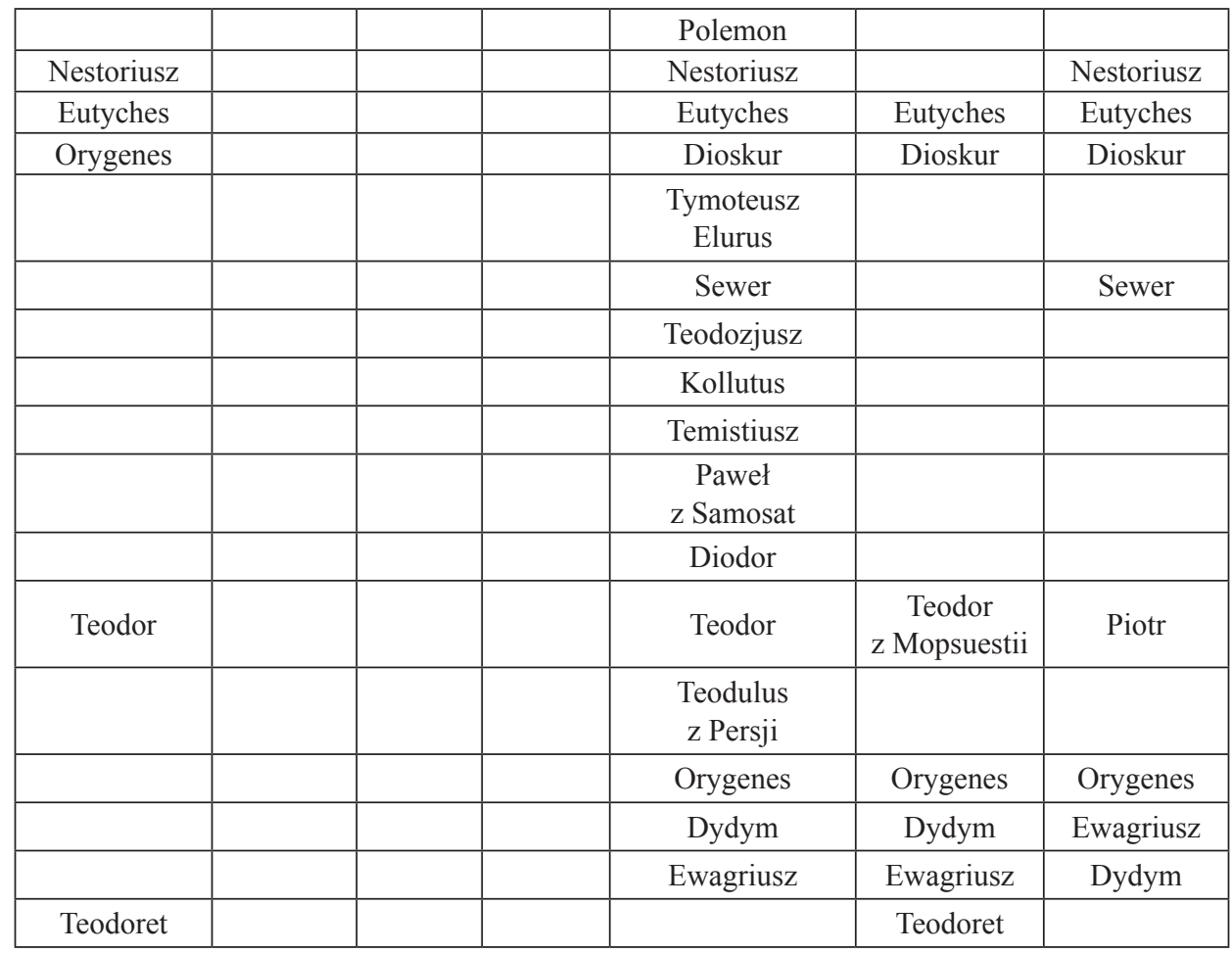

To, co uderza w orzeczeniach zarówno III Soboru Konstantynopolitańskiego, jak też Nicejskiego II, to fakt, iż powtarzają one wyklęcia heretyków takich jak Ariusz, Eunomiusz czy Macedoniusz, którzy już od dawna nie zagrażali Kościołowi. Chodziło zapewne o pokazanie ciagłości potępiania kolejnych heretyków na wzór tamtych pierwszych soborów w Nicei (325) i Konstantynopolu (381), a także o podtrzymanie nauki wcześniejszych soborów. Tabelka, pokazuje, że na Synodzie Laterańskim (649), Konstantynopolitańskim III (680-681) i Nicejskim II (787) Ewagriusz jest potępiany razem z Orygenesem i Dydymem, rzekomo na podstawie wcześniejszych potępień na Soborze Konstantynopolitańskim II (553), ale tam takiego potępienia nie znajdujemy. Można oczywiście przyjąć założenie, że nawet jeśli Ewagriusz imiennie nie został potępiony na soborze w 553 r., ani w Dekrecie Justyniana przeciw Orygenesowi ani w 15 Anatematyzmach przeciw Orygensowi, a dopiero na Soborze Konstantynopolitańskim III i Nicejskim II, to już wystarczy, by uznać go w Kościele za heretyka. Cała sprawa jest bardziej skomplikowana, gdyż Sobór Konstantynopolitański III (680-681) i Nicejski II (787) tak naprawdę nie potępiają go, a jedynie powtarzają wcześniejsze potępienia, które nie zachowały się do naszych czasów. Dzisiejszy stan badań nad tą kwestią dobrze podsumowują Jean Gribomont i Daniel Hombergen: „Potępienie z 553 r. zostało 
dokonane prawdopodobnie przez jakiś synod (endemiczny) w Konstantynopolu, zwołany przez Justyniana krótko przed II Soborem Konstantynopolitańskim w 553 r., gdy uczestnicy byli już zgromadzeni w stolicy" "51. Pozostaje otwarty problem rozumienia tych orzeczeń nieobecnych w oficjalnych dokumentach Kościoła. Tutaj poprzestanę na konkluzji: nie mamy oficjalnych dokumentów Kościoła potwierdzających imienne potępienie Ewagriusza w VI w., a imienne wzmianki o nim na Soborze Konstantynopolitańskim III z lat 680-681 i Nicejskim II z 787 r., powołujące się na Sobór Konstantynopolitański II z 553 r., zawieszone są w próżni.

\section{WAS EVAGRIUS PONTICUS REALLY CONDEMNED?}

\section{(Summary)}

The article in the first part tries to prove on the basis of the arguments raised in recent studies, especially of A. Casiday, that there are no serious reasons to consider the syriac version S 2 of Kephalaia Gnostica as authentic and the version $\mathrm{S} 1$ as expurged from Origenism. It seems quite the contrary, the version S 1 would be authentic and S 2 would has been contaminated by Origenism of sixth century. So Evagrius would not be the central figure in the so-called first Origenist controversy in the fifth century.

In the second part author shows that the name of Evagrius does not appear in the Second Council of Constantinople in 553, in Epistula Synodum de Origene and in Edictum contra Origenem of Justinian. He was condemned probably only by some endemic synod before the official opening of the Council in 553. The question regarding the real validity of this condemnation still remains open. The III Council of Constantinople in 680-681, II Nicean in 787 and patristic authors simply repeat the condemnation of the previus endemic synod without examining the case.

Key words: Evagrius Ponticus, origenism, ancient Councils of the Church.

Słowa kluczowe: Ewagriusz z Pontu, orygenizm, starożytne sobory Kościoła.

\section{BIBLIOGRAFIA}

\section{Źródła}

Concilium Constantinopolitanum III, Sacrorum Conciliorum Nova et Amplissima Collectio, ed. J.D. Mansi, X, Florentiae 1763, 368-388; Conciliorum Oecumenicorum Decreta, ed. G. Alberigo et al., Colonia 1991, 107-122, tłum. A. Baron, w: DSP 1, red. A. Baron - H. Pietras, ŹMT 24, Kraków 2001, 262-303.

${ }^{51}$ J. Gribomont - D. Hombergen, Evagrio Pontico, NDPAC I 1880: „La condanna del 553 fu pronunciata probabilmente da un sinodo a Costantinopoli, convocato da Giustiniano poco prima del grande concilio ecumenico (Costantinopoli II), quando i pertecipanti furono già radunati nella capitale", thum. własne. 
Concilium Lateranense (649), Sanctorum Conciliorum Nova et Amplissima Collectio, ed. J.D. Mansi, X, Florentiae 1763; Concilium Lateranense a. 649 celebratum, ed. R. Riedinger, Berlin 1984.

Cyrillus Scytopolitanus, Vita S. Sabae, w: Kyrillos von Skythopolis, ed. E. Schwartz, TU 9/2, Leipzig 1939, thum. E. Dąbrowska: Cyryl ze Scytopolis, Żywot świętego Saby, w: Cyryl ze Scytopolis, Żywoty mnichów palestyńskich, red. M. Gronowski, ŹM 60, Kraków - Tyniec 2011, 419-450.

Cyrillus Scytopolitanus, Vita S. Cyriaci, w: Kyrillos von Skythopolis, ed. E. Schwartz, TU 9/2, Leipzig 1939, tłum. E. Dąbrowska: Cyryl ze Scytopolis, Żywot świętego Cyriaka, w: Cyryl ze Scytopolis, Żywoty mnichów palestyńskich, red. M. Gronowski, ŹM 60, Kraków - Tyniec 2011, 451-470.

Evagrius Ponticus, Practicus, ed. C. Guillaumont - A. Guillaumont, Évagre le Pontique. „,Traité pratique ou le Moine”, I-II, SCh 170-171, Paris 1971, thum. E. Kędziorek: Ewagriusz z Pontu, O praktyce ascetycznej, w: Ewagriusz z Pontu, Pisma ascetyczne, t. 1, ŹM 18, Kraków - Tyniec 1998, 201-230.

Evagrius Ponticus, Gnosticus, w: Évagre le Pontique. „Le Gnostique ou à celui qui est devenu digne de la science”, ed. C. Guillaumont - A. Guillaumont, SCh 356, Paris 1989, thum. K. Bielawski: Ewagriusz z Pontu, O poznaniu, w: Ewagriusz z Pontu, Pisma ascetyczne, I, ŻM 18, Kraków - Tyniec 1998, 231-245.

Evagrius Ponticus, De malignis cogitationibus, w: Évagre le Pontique. Sur les pensées, ed. P. Géhin - C. Guillaumont - A. Guillaumont, SCh 438, Paris 1998, tłum. L. Nieścior: Ewagriusz z Pontu, O różnych rodzajach złych myśli, BOK 26, Kraków 2006, 15-53.

Evagrius Ponticus, Kephalaia Gnostica, w: Les six Centuries des „Kephalaia gnostica” d'Évagre le Pontique. Édition critique de la version syriaque commune et édition d'une nouvelle version syriaque intégrale avec une double traduction francaise, ed.

A. Guillaumont, Patrologia Orientalis 28/1, Paris 1958, 15-257.

Evagrius Ponticus, Scholia in Proverbia, w: Évagre le Pontique. „Scholies aux Proverbes”, ed. P. Géhin, SCh 340, Paris 1987, 90-475.

Evagrius Ponticus, Scholia in Ecclesiasten; w: Évagre le Pontique. „Scholies à l'Ecclésiaste”, ed. P. Géhin, SCh 397, Paris 1993, 58-177.

Evagrius Ponticus, Antirheticus, w: Evagrius Ponticus, ed. W. Frankenberg, Berlin 1912, 472-545.

Evagrius Scholasticus, Historia Ecclesiastica, PG 86, 2415-2886, thum. S. Kazikowski: Ewagriusz Scholastyk, Historia Kościoła, Warszawa 1990.

\section{Opracowania}

BARon A., Synody czasów upadku i przemiany Imperium Rzymskiego na Zachodzie, PS 29 (2011) 5-36.

Bunge G., Origenismus - Gnosticismus. Zum geistgeschichtlichen Standort des Evagrios Pontikos, VigChr 40 (1986) 24-45.

Casiday A., Reconstructing the Theology of Evagrius Ponticus. Beyond Heresy, Cambridge 2013.

Clark E., The Origenist Controversy: The Cultural Construcation of an Early Christian Debate, Princeton 1992.

Diekamp F., Die origenistischen Stretigkeiten im sechsten Jahrhundert und das fünfte allgemeine Concil, Münster 1899.

Dysinger L., The Condemnation of Evagrius Recondsidered, Paper read at the Oxford Patristic Conference, August 22, 2003, w: https:/www.academia.edu/10129054/The Condemnation_of_Evagrius_Reconsidered,[dostęp 04.03.2016]. 
GARnier J., De quinta synodo generali, Lutetia Parisiorum 1684.

GÉHIN P., Evagriana d'un manuscrit basilien, „Muséon” 109 (1966) 59-85.

Grimbont J. - Hombergen D., Evagrio Pontico, NDPAC I 1879-1881.

Guillaumont A., Évagre et les anathématismes antiorigénistes de 553, StPatr 12 (1961) 219-226.

Guillaumont A., Les Kephalaia Gnostica d'Evagre le Pontique et l'histoire de l'origenisme chez les Grecs et chez les Syriens, Paris 1962.

Guillaumont C. - Guillaumont A., Le texte veritable des „Gnostica” d'Évagre le Pontique, RHR 142 (1952) 156-205.

HAUSHERR I., Les versions syriaque et armenienne d'Evagre le Pontique: leur valeur, leur relation, leur utilization, OCP 22 (1931) 69-118.

Hausherr I., Nouveaux fragments grecs d'Evagre le Pontique, OCP 5 (1939) 229-233.

Hefele CH.J., The History of the Councils of the Church from the Original Documents, IV, Edinburgh 1895.

Hombergen D., The Second Origenist Controversy. A New Perspective on Cyril of Scythopolis' Monastic Biographies as Historical Sources for Sixth-Century Origenism, Roma 2001.

Konstantinovsky J., Evagrius Ponticus. The Making of a Gnostic, Farnham 2009.

Misiarczyk L., Osiem logismoi w pismach Ewagriusza z Pontu, Kraków - Tyniec 2007.

Muyldermans J., Evagriana. Extrait de la revue „Muséon”, vol. 42, augmenté de nouveaux fragments grecs inédits, Paris 1931, 52-59.

Muyldermans J., A travers la tradition manuscrite d'Évagre le Pontique. Essai sur le manuscrits grecs conservés à la Bibliotheque Nationale de Paris, Louvain 1932.

Noris H., Dissertatio Historica de Synodo Quinta Oecumenica, Viennae 1703.

Potz R., Patriarch und Synode in Konstantinopel, Wien 1971.

PRzeKop E., Wschodnie patriarchaty starożytne, Warszawa 1984.

REFoulé F., Évagre fut-il Origéniste, RSPT 47 (1963) 398-402.

Young R.D., The Armenian adaptation of Evagrius' Kephalaia Gnostica w: Origeniana Quinta, red. R.J. Daly, Leuven 1992, 535-541. 
